\title{
Jurist-Diction
}

Volume 4 No. 6, November 2021

\section{Pertanggungjawaban Pidana Penyelenggara Aplikasi Virtual Loan Dalam Penagihan Pinjaman Online Dengan Ancaman, Asusila dan Pornografi}

\author{
Dina Aprilia \\ dina11aprilia@gmail.com \\ Universitas Airlangga
}

\author{
How to cite: \\ Dina Aprilia, \\ 'Pertanggungjawaban Pidana \\ Penyelenggara Aplikasi \\ Virtual Loan Dalam Penagihan \\ Pinjaman Online Dengan \\ Ancaman, Asusila dan \\ Pornografi' (2021) Vol. 4 No. 6 \\ Jurist-Diction. \\ Histori artikel: \\ Submit 7 April 2021; \\ Diterima 15 Oktober 2021; \\ Diterbitkan 5 November 2021. \\ DOI: \\ 10.20473/jd.v4i6.31847 \\ p-ISSN: $2721-8392$ \\ e-ISSN: $2655-8297$
}

\begin{abstract}
Virtual loan companies comes with an app that facilitates meetings between creditors and debtors for the purpose of making a loan agreement. The provider of virtual loan owns a right to collect debtor's debt in accordance with operation agreement. However, in practice they commit threats, immorality and pornography using personal data. So this research aims to determine the criminal act and criminal responsibility of the companies. The way of collecting indication of criminal act is not only carried out by virtual loan legal, but also those are illegal. This thesis used juridical-normative legal research by using the statue, conceptual and case approach. The results show that criminal acts committed by the providers may be subject to Article 27 paragraph (1) or (4) of the ITE Law. Illegal providers, through their management, participated in this act as "medeplichtige" because they provides a means of accessing personal data that is used to threaten. Keywords: Threat; Immorality; Loan; Pornography.
\end{abstract}

\section{Abstrak}

Perusahaan pinjaman virtual hadir dengan aplikasi yang memfasilitasi pertemuan antara kreditur dengan debitur untuk melakukan perjanjian pinjam-meminjam. Penyelenggara aplikasi virtual loan berhak untuk menagihkan utang debitur berdasarkan perjanjian penyelenggaraan. Namun, dalam praktiknya mereka melakukan ancaman, asusila dan pornografi dengan memanfaatkan data pribadi debitur. Sehingga penelitian ini bertujuan untuk mengetahui tindak pidana dan pertanggungjawaban pidana penyelenggara aplikasi virtual loan dalam penagihan pinjaman online dengan ancaman, asusila dan pornografi. Penelitian ini menggunakan metode penelitian hukum yuridisnormatif dengan menggunakan pendekatan perundang-undangan, konseptual dan kasus. Hasil penelitian menunjukkan bahwa tindak pidana yang dilakukan oleh penyelenggara dapat dikenakan Pasal 27 ayat (1) atau ayat (4) UU ITE. Penyelenggara aplikasi virtual loan ilegal, melalui pengurusnya turut membantu perbuatan tersebut sebagai "medeplichtige" karena menyediakan sarana berupa akses data pribadi yang dimanfaatkan untuk mengancam.

Kata Kunci: Ancaman; Asusila; Pinjaman; Pornografi.

Copyright (C) 2021 Dina Aprilia 


\section{Pendahuluan}

Revolusi industri adalah periode waktu pada saat pekerjaan lebih banyak dilakukan dengan mesin daripada dengan tangan di rumah. Saat ini Indonesia sedang menghadapi revolusi industri 4.0 yang dipicu oleh perkembangan teknologi Informasi dan Transaksi Elektronik (ITE) yang didasarkan pada automatisasi 'cerdas'. Dengan berada di fase revolusi industri ini, perkembangan teknologi berkembang pesat dan membawa perubahan dalam peningkatan kesejahteraan dan peradaban manusia. Di sisi lain, kemajuan teknologi ITE dapat dimanfaatkan untuk melakukan perbuatan-perbuatan yang bersifat melawan hukum. Sejalan dengan kemajuan teknologi, hukum pidana harus mengikutinya. Apabila tidak diikuti oleh hukum pidana, perkembangan dan kemajuan teknologi informasi secara faktual akan mempengaruhi perubahan kegiatan peradaban manusia dan berdampak sangat buruk. ${ }^{1}$

Financial technology (fintech) merupakan salah satu inovasi di bidang finansial yang mengacu pada teknologi modern. Teknologi finansial merupakan teknologi dalam sistem keuangan yang menghasilkan suatu produk, layanan, teknologi, dan/ atau model bisnis baru dalam perdagangan jasa keuangan di Indonesia. Menurut Hsueh, salah satu tipe fintech adalah fintech peer to peer (P2P) lending. Dalam fintech P2P lending, setiap orang dapat mengajukan pinjaman atau saling memberikan pinjaman tanpa menggunakan perantara lembaga perbankan karena persyaratan pinjaman bank cukup tinggi. Sehingga fintech P2P lending adalah inovasi pada industri jasa keuangan yang memanfaatkan penggunaan teknologi yang terbatas pada transaksi pinjam meminjam saja.

Otoritas Jasa Keuangan (OJK) menggunakan istilah Layanan Pinjam Meminjam Berbasis Teknologi Informasi (LPMUBTI) dalam pengaturan mengenai fintech P2P lending. LPMUBTI adalah penyelenggara-an layanan jasa keuangan untuk mempertemukan pemberi pinjaman dan peminjam dalam rangka perjanjian pinjam meminjam secara langsung melalui sistem internet. Menurut penjelasan UU

\footnotetext{
${ }^{1}$ Adami Chazawi dan Ardi Ferdian, Tindak Pidana Informasi\&Transaksi Elektronik (Media Nusa Creative 2011).[2].
} 
ITE, istilah lain yang digunakan dalam hukum terkait dengan pemanfaatan teknologi dan informasi (cyber law) yaitu virtual world law (hukum dunia maya). Teknologi informasi yang dimanfaatkan berbasis sistem elektronik yang dapat dilihat secara virtual. Virtual di artikan sebagai aktivitas yang dilakukan dalam cyberspace yang menawarkan realitas (termasuk experience pengguna) secara tidak langsung dan tidak nyata. Penulis menggunakan istilah virtual loan karena pertemuan pemberi pinjaman dan peminjam tidak secara langsung, yaitu di aplikasi virtual dalam cyberspace. Sehingga digunakan istilah virtual loan dalam penulisan ini.

Penyediaan, pengelolaan dan pengoperasian LPMUBTI dilakukan oleh penyelenggara. Dalam pengoperasiannya, penyelenggara menggunakan teknologi perangkat lunak komputer sehingga penyelenggara LPMUBTI dapat disebut sebagai penyelenggara aplikasi virtual loan. Penyelenggara virtual loan berperan sebagai wadah yang mempertemukan pemberi pinjaman (kreditur) dengan penerima pinjaman (debitur). Sesuai POJK No. 77 Tahun 2016, penyelenggara aplikasi berupa badan hukum yang memiliki sistem untuk melaksanakan mekanisme transaksi pinjam meminjam secara online, baik melalui aplikasi maupun laman website.

Perbuatan fintech dalam penyediaan, pengelolaan dan pengoperasian LPMUBTI yang berpotensi menyebabkan kerugian calon konsumen, yaitu: (a) Memberikan informasi seolah-olah dirinya telah terdaftar di OJK agar menarik calon konsumen untuk menggunakan jasanya. (b) Ketentuan dalam perjanjian pinjam-meminjam di aplikasi tersebut mengandung klausula baku. (c) Debitur tidak menerima pagu pinjaman sesuai dengan yang telah disepakati dalam pemberian pinjaman. (d) Tidak adanya jaminan dan credit scoring untuk menentukan kemampuan pembayaran debitur.

Hal tersebut berdampak pada munculnya risiko ketika melakukan pinjaman online. Beberapa risiko dari pinjaman online, yaitu: Pertama, total tagihan di akhir pinjaman yang sangat banyak. Kedua, bocornya data pribadi saat mengajukan pinjaman online. Ketiga, desk collector memanfaatkan data elektronik debitur yang bersifat pribadi ketika menagih pinjaman. Keempat, debitur berisiko terkena cyber bullying. Dan masih banyak risiko lain yang mengakibatkan munculnya beberapa korban. 
Korban pinjaman online ilegal yang sempat viral adalah YI. YI menerima teror melalui pesan secara bertubi-tubi karena tidak sanggup membayar utang senilai Rp. 1.054.000,-. Lebih parah dari itu, YI menjadi korban dari informasi hoaks yang menyebut dirinya rela 'digilir' agar dapat membayar utang. Korban lainnya adalah SM. Ia meminjam uang sebesar Rp. 5 juta, menunggak pembayaran selama 2 bulan dan tiba-tiba total tagihan yaitu Rp. 75 juta karena harus ditambah dengan biaya pinalti (denda), biaya perpanjangan tenor, dan bunga. Korban bernama Zulfadli, seorang sopir taksi yang bunuh diri yang tidak kunjung membayar utang, padahal pinjaman awal hanya Rp. 500.000,-. Korban bernama AA mendapat pesan dengan kata kasar dan menyiratkan ancaman pada aplikasi whatsapp lalu meminta untuk membayar utang temannya di platform RupiahPlus.

OJK melalui satgas waspada investasi seharusnya mampu untuk melakukan tindakan penegakan hukum bukan hanya kepada perusahaan-perusahaan fintech lending legal saja, melainkan juga yang ilegal. Selain itu sejauh ini yang dipidana hanya desk collectornya saja dan bukan korporasinya. Kasus Dompet Kartu oleh PT. Barracuda Fintech Indonesia merupakan salah satu contoh kasus penagihan pinjaman online yang tidak hanya berpraktik secara ilegal melainkan manajemennya juga melakukan pengancaman, fitnah dan pencemaran nama baik dalam upaya penagihan kepada konsumennya. Bayu Prasetya yang merupakan korban penagihan pinjaman online, medapatkan pesan dari desk collector berupa ancaman yang isinya akan mendatangi rumah korban dengan senjata tajam dan “membantai" keluarga korban.

\section{Metode Penelitian}

Metode penelitian dari penulisan jurnal ini adalah metode yuridis normatif. Penelitian hukum yuridisnormatifadalahpenelitian yangmengacupadanorma-norma hukum yang terdapat dalam peraturan perundang-undangan, konvensi internasional dan putusan pengadilan. Penulisan jurnal ini menggunakan pendekatan perundangundangan (statute approach), pendekatan konseptual (conceptual approach) dan pendekatan kasus (case approach). Pendekatan perundang-undangan yaitu penulis 
menggunakan peraturan-peraturan yang berlaku di Indonesia dalam menganalisis permasalahan. Pendekatan konseptual yaitu penulis nantinya menjelaskan konsep penagihan pinjaman online, konsep ancaman, asusila dan pornografi, konsep tindak pidana dan konsep pertanggungjawaban pidana. Dan pendekatan kasus berarti digunakan putusan terkait yang telah inkracht dalam jurnal ini.

\section{Konsep Penagihan Pinjaman Online}

Perjanjian dasar dari pinjaman online adalah perjanjian pinjam-meminjam. Perjanjian pinjam-meminjam merupakan salah satu bentuk perjanjian yang diatur di Pasal 1754 BW. Pasal 1338 BW mengatur mengenai asas freedom of contract atau kebebasan berkontak. Dengan adanya asas freedom of contract ini, diperbolehkan adanya perjanjian pinjam-meminjam secara online asal tetap memperhatikan syarat sah perjanjian sesuai Pasal 1320 BW.

Dasar dari kewajiban penyelenggara untuk menagihkan utang debitur yang sudah jatuh tempo adalah perjanjian penyelenggaraan sesuai Bab IV POJK No. 77 Tahun 2016. Diatur di Pasal 19 ayat (1) POJK No. 77 Tahun 2016 bahwa perjanjian penyelenggaraan LPMUBTI antara penyelenggara dengan pemberi pinjaman dituangkan dalam dokumen elektronik. Salah satu klausula dalam perjanjian penyelenggaraan adalah memuat hak dan kewajiban para pihak. Menagihkan pinjaman yang sudah jatuh tempo merupakan kewajiban penyelenggara virtual loan.

Penagihan ialah tindakan menginformasikan, mengingatkan dan/atau memperingatkan pihak yang tertagih bahwa ia mempunyai kewajiban berupa utang yang harus dibayarkan kepada pihak penagih. Penagihan yang dilakukan dalam pinjaman online dilakukan secara virtual. Sarana yang dimanfaatkan adalah sistem elektronik dan jaringan internet. Internet atau interconnected network adalah jaringan yang terhubung diantara sistem yang terdigitalized. Karena dilakukan dengan memanfaatkan jaringan internet, hukum yang berlaku untuk penagihan dengan cara-cara yang berindikasi tindak pidana adalah cyber law. Cyber law adalah aspek hukum yang ruang lingkupnya meliputi setiap aspek yang berhubungan dengan orang perorangan atau subjek hukum dengan menggunakan 
dan memanfaatkan teknologi internet yang dimulai pada saat media online dan memasuki dunia cyber (dunia maya).

Penyelenggara virtual loan memanfaatkan kemudahan teknologi informasi untuk menyediakan platform pinjaman online berupa aplikasi. Aplikasi tersebut diselenggarakan oleh penyelenggara sistem elektronik yang diatur di Pasal 1 Angka 6a UU ITE yaitu penyelenggara negara, orang, badan usaha dan masyarakat. Namun penyelenggara sistem elektronik yang dapat menjadi penyelenggara virtual loan adalah badan hukum saja sesuai POJK No. 77 Tahun 2016.

Pelaku yang melakukan penagihan pinjaman dalam virtual loan ini adalah desk collector. Desk collector adalah orang yang menjual jasa untuk menagih utang seseorang atau lembaga yang menyewa jasa mereka dengan menggunakan alat bantu smartphone, komputer dan data. Desk collector memanfaatkan data pribadi yang terdapat dalam smartphone untuk mengancam pengguna aplikasi yang utangnya telah jatuh tempo.

Perolehan data pribadi yang nantinya dimanfaatkan oleh desk collector dalam penagihan pinjaman online didapatkan dengan intersepsi data. Intersepsi adalah kegiatan untuk mendengarkan, merekam, membelokkan, mengubah, menghambat, dan/atau mencatat transmisi informasi elektronik dan/atau dokumen elektronik yang bersifat privat, baik menggunakan jaringan kabel komunikasi maupun jaringan nirkabel, seperti pancaran elektromagnetis atau radio frekuensi. Intersepsi atau penyadapan ini diatur di Pasal 31 ayat (1) UU ITE.

Faktor utama yang menyebabkan adanya tindak pidana dalam penagihan yang dilakukan oleh desk collector ialah data pribadi yang diakses oleh penyelenggara. Penyelenggara virtual loan mengakses data pribadi calon nasabah seperti mengambil semua nomor di daftar kontak dan foto dalam gallery ponsel nasabah. Padahal dalam surat direktur pengaturan, perizinan, dan pengawasan fintech nomor: S-72/NB.213/2019 tentang perintah pembatasan akses data pribadi pada ponsel pengguna virtual loan, mengatur bahwa yang diperbolehkan untuk diakses perusahaan hanya kamera, lokasi dan mikrofone, selain 3 (tiga) akses tersebut tidak diperbolehkan. 
Baik virtual loan legal ataupun ilegal dapat melakukan penyimpangan dalam penagihan terhadap debiturnya. Perbedaan kedua virtual loan tersebut hanya pada masalah perizinan. Virtual loan legal yang sudah mendapatkan izin OJK dan berada di bawah pengawasan OJK juga mempunyai kemungkinan untuk melakukan penyimpangan dari etika penagihan, namun virtual loan mempunyai kemungkinan lebih besar untuk melakukan penyimpangan dari etika penagihan. Menjadi masalah ketika penagihan pinjaman dengan cara-cara yang berindikasi tindak pidana seperti dengan ancaman, asusila dan pornografi.

Permasalahan perdata dapat menjadi pidana apabila ada mens rea dalam suatu perbuatan. Mens rea terletak pada cara penagihan dengan ancaman, asusila dan pornografi. Menurut Utrecht, hukum pidana tidak membuat norma atau kaidah baru, hanya menegaskan norma yang ada di bagian hukum lain (hukum privat, hukum perburuhan, dan sebagainya) dan dilengkapi dengan ancaman hukuman. ${ }^{2}$ Hukum perdata tidak memadahi dalam menjatuhkan sanksi perdata kepada pelaku penagihan pinjaman dengan ancaman, asusila dan pornografi sehingga hukum pidana digunakan untuk memulihkan keseimbangan itu.

\section{Tindak Pidana Dalam Penagihan Pinjaman Online}

\section{Ancaman}

\subsection{Ancaman kekerasan}

Menurut Simons, pengertian kekerasan yaitu setiap penggunaan tenaga badan dan/atau fisik yang tidak terlalu ringan. Tindakan kekerasan ini dapat berupa memukul, mengikat, menjambak, dan lainnya. Menurut Moch. Anwar, ancaman kekerasan adalah setiap perbuatan yang sedemikian rupa sehingga menimbulkan akibat rasa takut atau cemas pada orang yang diancamnya. ${ }^{3}$ Menurut R. Soesilo, melakukan kekerasan ialah mempergunakan tenaga atau kekuatan jasmani tidak kecil secara tidak sah, misalnya memukul, menendang

\footnotetext{
${ }^{2}$ Utrecht, Hukum Pidana I (Pustaka Tinta Mas 1987).[64].

${ }^{3}$ H.A.K. Moch Anwar, Hukum Pidana Bagian Khusus Jilid I (Citra Aditya Bakti 1982).[53].
} 
dan menyepak. ${ }^{4}$

Berdasarkan pengertian diatas, kekerasan hanya dapat dilakukan jika penagihan dilakukan secara langsung. Sedangkan penagihan pinjaman online dilakukan oleh desk colletor yang bertugas mengingatkan tanggal jatuh tempo dari cicilan debitur melalui media telepon. Desk collector tidak segan untuk mengancam mendatangi rumah debitur dengan membawa senjata tajam agar debitur segera membayar utangnya walaupun menagih secara langsung bukan merupakan job desc dari desk collector.

Terdapat perbedaan tipis antara ancaman kekerasan yang diatur di Pasal 368 KUHP dan paksaan kekerasan yang diatur di Pasal 335 ayat (1) nomor 1 KUHP. Apabila barang yang diminta dengan kekerasan adalah milik pelaku sendiri, maka ia tidak dapat dipersalahkan melakukan tindak pidana pemerasan dari Pasal 368 KUHP, tetapi ia dapat dihukum berdasarkan Pasal 335 ayat (1) nomor 1 KUHP yang melarang tiap perbuatan paksaan dengan kekerasan. ${ }^{5}$ Desk Collector yang mempunyai tugas menagihkan utang debitur yang sudah jatuh tempo, melakukan pemaksaan dengan kekerasan terhadap agar debitur segera membayar utangnya.

\subsection{Ancaman pencemaran}

Pencemaran disebutkan dalam Bab XVI KUHP tentang penghinaan. Berdasarkan penjelasan Pasal 310 KUHP, definisi penghinaan yaitu menyerang kehormatan dan nama baik seseorang. Kehormatan merupakan perasaan harga diri yang ada dalam batin setiap orang (bersifat intern) sedangkan nama baik merupakan sikap penghargaan yang dinilai masyarakat dari sikap atau kedudukan setiap orang (bersifat ekstern). ${ }^{6}$ R. Soesilo manyatakan bahwa terdapat enam macam penghinaan dalam KUHP, salah satunya adalah pencemaran nama baik.

\footnotetext{
${ }^{4}$ R. Soesilo, Kitab Undang-Undang Hukum Pidana (KUHP) Serta Komentar-Komentarnya Lengkap Pasal Demi Pasal (Politeia 1991).[98].

5 Wirjono Prodjodikoro, Tindak-Tindak Pidana Tertentu Di Indonesia (Refika Aditama 2003).[28].

${ }^{6}$ Bunga Upe, Haerani Husainy dan Abd. Malik Bram, 'Tinjauan Yuridis Pencemaran Nama Baik Melalui Media Sosial' (2019) Vol. 1 No.1 Jurnal Unismuh Palu.[2033].
} 
Pencemaran nama baik dilakukan dengan dua cara yaitu melalui lisan ataupun tulisan. Saat ini, masyarakat banyak yang menjadi pengguna aktif media sosial, sehingga banyak ditemukan perbuatan pencemaran nama baik yang dilakukan di media sosial. Perbuatan pencemaran nama baik yang dilakukan desk collector adalah dengan mempersamakan debitur dengan maling lalu menginformasikan ke orang-orang yang ada di daftar kontak debitur hanya karena belum membayar utangnya yang sudah jatuh tempo. Padahal hal tersebut merupakan perbuatan wanprestasi.

\section{Asusila}

Kata "kesusilaan" berasal dari kata susila, kesusilaan mempunyai pengertian baik budi bahasa, sopan santun, keadaban, adat istiadat dan tertib yang baik. Menurut Leden Marpaung, tindakan asusila berarti tindakan yang berlawanan dengan arti kesusilaan dan berhubungan dengan permasalahan kesusilaan (etika). Batasan-batasan kesusilaan tergantung dari nilai-nilai yang berlaku dalam suatu masyarakat. Sehingga tindak pidana asusila yaitu tindak pidana yang melanggar norma kesusilaan. Menurut Widyanto, tindakan asusila ialah perilaku yang tidak sesuai dengan aturan nilai dan norma serta kaidah kesopanan yang berlaku di masyarakat. ${ }^{7}$

Tindakan asusila dalam penagihan pinjaman online seringkali ditemukan dalam bentuk pornografi dan pelecehan seksual. Pelecehan seksual dapat dilakukan secara verbal dan non-verbal. Modus operandi yang dilakukan oleh desk collector yaitu menyebarluaskan informasi dan/atau dokumen elektronik yang bermuatan asusila menggunakan media komunikasi berbasis teknologi. Terdapat salah satu korban yang berinisial YI, diiklankan oleh desk collector dalam poster dengan menampilkan foto disertai keterangan 'rela digilir dengan harga Rp. 1.054.000,- untuk melunasi utangnya di aplikasi yang bernama Incash'. Poster tersebut merupakan dokumen elektronik yang berisi data pribadi debitur berupa foto lalu di edit sedemikian rupa sehingga menjadi

\footnotetext{
7 Taufiq Widyanto, 'Perlindungan Hak Perempuan Perbuatan Asusila Ditinjau dari Perspektif Hukum Pidana’ (2014), Jurnal Ilmiah Ilmu Hukum.[5].
} 
bermuatan asusila. Dokumen elektronik yang bermuatan asusila tersebut telah disebarkan ke teman, keluarga ataupun rekan debitur yang sudah tergabung dalam grup whatsapp.

\section{Pornografi}

Definisi pornografi diatur di Pasal 1 Angka 1 Undang-Undang Nomor 44 Tahun 2008, pornografi ialah gambar, sketsa, ilustrasi, foto, tulisan, suara, bunyi, gambar bergerak, animasi, kartun, percakapan, gerak tubuh, atau bentuk pesan lainnya melalui berbagai bentuk media komunikasi dan/atau pertunjukan di muka umum, yang memuat kecabulan atau eksploitasi seksual yang melanggar norma kesusilaan dalam masyarakat. Pornografi berasal dari bahasa Yunani yaitu porne dan graphein yang secara harfiah artinya ialah tulisan tentang pelacur. Menurut KBBI, pornografi ialah gambaran tingkah laku secara erotis dengan lukisan dan/ atau tulisan untuk membangkitkan nafsu birahi.

Modus operandi dalam penagihan pinjaman online adalah desk collector mengirimkan pesan berbau pornografi atau sexual harassment kepada korban yang sudah tergabung dalam grup whatsapp. Dalam kasus aplikasi vloan, terdapat percakapan grup whatsapp atas nama Ivo Wulandandarisa yang menerima pesan berupa video porno. Pesan yang dikirimkan oleh desk collector juga dapat dikategorikan pelecehan seksual dan melanggar norma kesusilaan. Anggota grup whatsapp menerima penyebaran pornografi dari desk collector sehingga mereka juga dapat dikatakan sebagai korban.

\section{Pengaturan Terkait Penagihan Pinjaman Online Dengan Ancaman, Asusila Dan Pornografi Di UU ITE}

Penagihan pinjaman online dengan ancaman, asusila dan pornografi merupakan tindak pidana di bidang ITE. Karena ancaman pembunuhan melalui internet merupakan pelanggaran terhadap kepentingan hukum nyawa dan penghinaan melalui internet merupakan pelanggaran terhadap kepentingan hukum kehormatan, yang keduanya merupakan jenis pelanggaran terhadap kepentingan hukum dalam lingkup cyber crime. Didukung dengan pendapat Nasura Abdul Manap, salah satu 
kategori cyber crime adalah cybercrimes against-persons yang meliputi pornografi, cyber harassment, cyber-stalking dan cyber-trespass. ${ }^{8}$

Berdasarkan Undang-Undang Nomor 11 Tahun 2008 Jo. Undang-Undang Nomor 19 Tahun 2016 Tentang Informasi dan Transaksi Elektronik (UU ITE), subjek hukum dalam UU ITE adalah orang, badan hukum dan badan usaha. Penyelenggara virtual loan yang wajib berbadan hukum dapat dikenakan aturan dalam UU ITE. Jenis tindak pidana di bidang ITE yang sesuai adalah: Pertama, tindak pidana mendistribusikan informasi elektronik yang bermuatan pengancaman diatur di Pasal 27 ayat (3) dan ayat (4) UU ITE. Kedua, tindak pidana mendistribusikan informasi elektronik yang melanggar kesusilaan diatur di Pasal 27 ayat (1) UU ITE. 1 Pasal 27 ayat (3) UU ITE: "Setiap orang dengan sengaja dan tanpa hak mendistribusikan dan/atau mentrasmisikan dan/atau membuat dapat diaksesnya Informasi Elektronik dan/atau Dokumen Elektronik yang memiliki muatan penghinaan dan/atau pencemaran nama baik".

2 Pasal 27 ayat (4) UU ITE: "Setiap orang dengan sengaja dan tanpa hak mendistribusikan dan/atau mentrasmisikan dan/atau membuat dapat diaksesnya Informasi Elektronik dan/atau Dokumen Elektronik yang memiliki muatan pemerasan dan/atau pengancaman”.

3 Pasal 27 ayat (1) UU ITE: "Setiap orang dengan sengaja dan tanpa hak mendistribusikan dan/atau mentransmisikan dan/atau membuat dapat diaksesnya Informasi Elektronik dan/ atau Dokumen Elektronik yang memiliki muatan yang melanggar kesusilaan”.

Ditinjau dari ketiga pasal tersebut, terdapat beberapa persamaan unsur penting, yaitu:

Pertama, unsur mendistribusikan, mentrasmisikan dan/atau membuat dapat diaksesnya. Dapat dilihatnya pengancaman, adanya konten asusila dan pornografi dalam grup whatsapp yang dikirim oleh desk collector menjelaskan bahwa terdapat proses pengiriman informasi elektronik dari ponsel milik desk

${ }^{8}$ Agus Raharjo, Cybercrime: Pemahaman dan Upaya Pencegahan Kejahatan Berteknologi (Citra Aditya Bakti 2002).[228]. 
collector ke aplikasi whatsapp. Proses pengiriman tersebut yaitu mendistribusikan informasi elektronik karena dikirimkan ke beberapa orang yang sudah tergabung dalam grup. Sesuai dengan penjelasan Pasal 27 ayat (1) UU ITE, mendistribusikan adalah mengirimkan dan/atau menyebarkan informasi elektronik kepada banyak orang melalui sistem elektronik.

Kedua, unsur informasi elektronik dan/atau dokumen elektronik. Objek perbuatan yaitu informasi elektronik dan/atau dokumen elektronik yang memiliki muatan melanggar kesusilaan. Definisi informasi elektronik dapat dilihat di Pasal 1 Angka 1 UU ITE. Dari pasal tersebut, dapat diketahui 3 (tiga) unsur pengertian informasi elektronik. Pertama, informasi elektronik adalah satu atau sekumpulan data elektronik. Kedua, memiliki wujud diantaranya tulisan, suara dan gambar. Ketiga, memiliki arti atau dapat dipahami. Sehingga pengancaman melalui pesan teks dan foto bermuatan asusila atau pornografi yang digunakan desk collector untuk mengancam merupakan informasi elektronik.

Ketiga, unsur muatan ancaman dan/atau pemerasan. Untuk membuktikan adanya unsur ini, harus membuktikan Pasal 89 jo. Pasal 335 ayat (1) nomor 1 KUHP karena merupakan lex specialis dari aturan mengenai ancaman dan paksaan dengan kekerasan di KUHP. Unsur muatan penghinaan dan/atau pencemaran. Sesuai dengan Putusan MK 50/PUU-VI/2008, Pasal 27 ayat (3) UU ITE tentang penghinaan merupakan delik aduan. Keberlakuan dan tafsir dari pasal ini tidak dapat dipisahkan dari norma hukum pokok dalam Pasal 310 dan Pasal 311 KUHP sebagai genus delict yang mensyaratkan adanya klacht (pengaduan) untuk dapat dituntut di depan pengadilan. Unsur muatan asusila, untuk membuktikan adanya unsur ini, harus membuktikan adanya pelanggaran kesusilaan yang diatur di Pasal 281-283 KUHP karena merupakan lex specialis dari aturan mengenai tindakan asusila di KUHP.

\section{Pelaku Tindak Pidana}

Pelaku tindak pidana dikenal sebagai subjek hukum yang dapat dibebani pertanggungjawabanpidana.Subjekhukumyangdapatdibebanipertanggungjawaban 
pidana berupa orang perorangan maupun korporasi. Dalam hal pelaku orang perorangan yang tidak melakukan penagihan pinjaman sendiri berlaku Pasal 55 KUHP mengenai penyertaan dan Pasal 56 KUHP mengenai pembantuan. Kedua pasal tersebut secara jelas menggolongkan pelaku tindak pidana menjadi 5 (lima) kategori, yaitu:

1. Orang yang melakukan (pleger);

2. Orang yang menyuruh melakukan (doen plegen);

3. Orang yang turut melakukan (medepleger);

4. Orang yang menghasut atau membujuk (uitlokker);

5. Orang yang membantu perbuatan (medeplichtige).

Penyelenggara virtual loan dapat melakukan penagihan sendiri, melalui karyawan di divisi penagihan. Apabila desk collector yang merupakan karyawan, menagih pinjaman online tidak sesuai dengan SOP penagihan yang mengatur bahwa penagihan tidak boleh dilakukan dengan ancaman, asusila dan pornografi maka ia dapat bertanggungjawab sebagai orang. Pengurus korporasi sebagai orang sesuai Pasal 59 KUHP juga dimungkinkan dikenakan penyertaan sesuai Pasal 55 KUHP sepanjang melakukan hal-hal yang memenuhi unsur. Namun, penyelenggara virtual loan juga dapat bertanggungjawab secara pidana sepanjang terdapat mens rea korporasi dan tidak ada SOP penagihan yang jelas.

Penyelenggara virtual loan yang tidak mempunyai divisi penagihan sendiri dapat meng-hire jasa penagihan pihak ketiga. Apabila penyelenggara virtual loan secara lisan menyatakan memperbolehkan penagihan dilakukan dengan cara apapun asal pinjaman menjadi tertagih (ada bukti saksi) maka orang yang melakukan penagihan merupakan turut serta sesuai Pasal 55 KUHP. Dapat dikategorikan turut melakukan atau turut membantu tergantung dari pembuktian.

Tindak pidana ancaman, asusila dan pornografi dalam penagihan pinjaman online tidak dapat dipertanggungjawabkan terhadap penyelenggara aplikasi virtual loan manakala dalam perjanjian diatur secara tegas mengenai penagihan harus dilakukan sesuai dengan tata cara penagihan dan apabila terdapat tindakan penagihan yang bertentangan dengan hukum merupakan tanggungjawab penagih. Dengan adanya klausula tersebut sudah membebaskan penyelenggara virtual 
loan dari pertanggungjawaban pidana terlebih jika didukung dengan adanya SOP penagihan yang menyatakan bahwa penagihan pinjaman tidak boleh dilakukan dengan perbuatan yang bertentangan dengan hukum.

\section{Pertanggungjawaban Pidana Penyelenggara Aplikasi}

Kejahatan yang dilakukan oleh penyelenggara aplikasi virtual loan merupakan corporate crime. David O. Friedrichs mendefinisikan kejahatan korporasi sebagai tindak pidana yang dilakukan oleh pengurus korporasi atau korporasi itu sendiri untuk kepentingan korporasi. ${ }^{9}$ Terdapat perbedaan tipis antara corporate crime dengan crime against corporation. Kejahatan dalam corporate crime dilakukan untuk kepentingan korporasi, sedangkan crime against corporation kejahatan dilakukan oleh karyawan korporasi dan ditujukan kepada korporasi.

Corporate crime seringkali menjadi bagian dari white collar crime. Definisi kejahatan kerah putih menurut Sutherland ialah kejahatan yang dilakukan oleh seseorang yang memiliki kehormatan dan status sosial tinggi dalam menjalankan jabatan. ${ }^{10}$ Status sosial dalam penyelenggara-an aplikasi virtual loan terlihat pada adanya modal yang dimiliki untuk meminjamkan uang. Kriteria lain dari kejahatan kerah putih yaitu didukung dengan kemampuan teknis di bidang ITE dan pengetahuan professional. ${ }^{11}$

Menurut Mahrus Ali, mens rea korporasi dapat dilihat ketika ada kemungkinan bagi korporasi untuk "dapat berbuat lain" selain tindak pidana. ${ }^{12}$ Namun penyelenggara virtual loan tidak menghindari terjadinya tindak pidana tersebut. Sesuai konsep utility maximizing approach menurut Boudon, tindakan korporasi didasari atas preferensi seseorang dalam menentukan pilihan perbuatan yang paling menguntungkan dan efektif bagi dirinya. ${ }^{13}$ Perbuatan tersebut didasari

\footnotetext{
9 Mahrus Ali, Asas-Asas Hukum Pidana Korporasi (RajaGrafindo Persada 2015).[9].

${ }^{10}$ ibid.[22].

${ }^{11}$ ibid. [24].

12 ibid. [153].

${ }^{13}$ Muhammad Naseh et al., 'Karakteristik Pelaku Kejahatan Transnasional Terorganisasi di Indonesia dan Eropa’ (2019), Vol. 8 No. 1 Jurnal Hubungan Internasional.[50].
} 
atas pilihan rasional (rational choice) dan alasan yang logis. Penyelenggara aplikasi virtual loan dalam menagih debitur seharusnya menggunakan upaya somasi atau gugatan perdata. Tetapi penagihan dengan proses perdata membutuhkan waktu yang tidak singkat. Sehingga penyelenggara memilih menagih dengan mengancam, menggunakan konten asusila dan pornografi yang hanya membutuhkan sedikit tenaga dan waktu.

Pertanggungjawaban pidana mensyaratkan adanya actus reus (perbuatan) pelaku dan mens rea (sikap batin atau kesalahan) pelaku. Cara untuk menentukan actus reus dan mens rea korporasi adalah dengan mengatribusi actus reus dan mens rea dari manusia alamiah kepada korporasi. Dalam perkembangannya, dikenal teori strict liability dan teori vicarious liability yang menjelaskan kapan korporasi dikatakan melakukan perbuatan pidana dan dalam hal apa korporasi dapat bertanggungjawab.

Menurut teori vicarious liability, korporasi bertanggungjawab atas perbuatan salah dari pelaku yang ada dalam ruang lingkup pekerjaannya. Yang memiliki kesalahan adalah agen korporasi, namun karena agen tersebut bertindak untuk kepentingan korporasi maka dapat menjadi kesalahan korporasi.${ }^{14}$ Kesalahan pelaku dapat digantikan oleh korporasi karena ada hubungan subordinasi antara pemberi kerja dan pelaku yang melakukan tindak pidana tersebut, serta keuntungan yang diperoleh pelaku sesungguhnya bukan keuntungan yang dimiliki pelaku namun keuntungan korporasi. Sehingga berdasarkan teori ini, korporasi dapat dimintai pertanggungjawaban pidana karena pelaku fisik adalah desk collector yang merupakan karyawan korporasi bertindak dalam lingkup pekerjaan serta untuk dan atas nama korporasi. Hasil penagihan pinjaman online merupakan keuntungan korporasi.

Teori identifikasi merupakan perkembangan dari teori vicarious liability. Menurut teori ini, selama tindakan dari agen tertentu (yang memiliki position official) berkaitan dengan korporasi maka dianggap sebagai tindakan dari korporasi itu sendiri, bukan sebagai pengganti. Kehendak korporasi harus dicari dan ditemukan

${ }^{14}$ ibid.[157]. 
dalam diri seseorang yang memiliki tujuan tertentu atau agen tertentu, yang benarbenar merupakan otak dan kehendak untuk mengarahkan (directing mind and will) dari korporasi tersebut. ${ }^{15}$ Menurut teori ini, agen yang merupakan directing mind dalam kasus ini adalah direktur. Direktur memberi fasilitas berupa sarana pengaksesan terhadap data pribadi debitur dan membiarkan terjadinya penagihan pinjaman online dengan memanfaatkan data pribadi. Sehingga perbuatan direktur dapat dikatakan sebagai perbuatan korporasi.

Pasal 4 ayat (1) Peraturan Mahkamah Agung Nomor 13 Tahun 2016 tentang tata cara penanganan perkara tindak pidana oleh korporasi mengatur bahwa korporasi dapat dimintakan pertanggungjawaban pidana sesuai dengan ketentuan pidana korporasi dalam undang-undang yang secara khusus mengatur (lex specialis). Dalam kasus penagihan oleh virtual loan ini, undang-undang yang secara khusus mengatur adalah UU ITE. Penyelenggara virtual loan yang merupakan badan hukum adalah subjek hukum UU ITE yang diatur di Pasal 1 Angka 21 UU ITE.

Pertanggungjawaban pidana korporasi di UU ITE hanya terdapat di Pasal 52 ayat (4) UU ITE. Diatur di pasal tersebut, tindak pidana yang dimaksud dalam Pasal 27-37 jika dilakukan oleh korporasi maka dipidana dengan pidana pokok ditambah dua pertiga. Penjelasan pasal ini menyatakan bahwa ketentuan ini dimaksudkan untuk menghukum setiap perbuatan melawan hukum yang memenuhi unsur Pasal 27-37 UU ITE yang dilakukan oleh korporasi (corporate crime) dan/atau oleh pengurus dan/atau staff yang memiliki kapasitas untuk:

a. Mewakili korporasi;

b. Mengambil keputusan dalam korporasi;

c. Melakukan pengawasan dan pengendalian dalam korporasi;

d. Melakukan kegiatan demi keuntungan korporasi.

Penagihan dengan cara ancaman, asusila dan pornografi dilakukan oleh desk collector memenuhi Pasal 27 ayat (1) atau ayat (4) tergantung dari muatan tindak pidana yang dilakukan. Pemidanaan yang dapat dijatuhkan adalah terhadap

\footnotetext{
${ }^{15}$ Abdurrakhman Alhakim, 'Kebijakan Pertanggungjawaban Pidana Korporasi Terhadap Pemberantasan Tindak Pidana Korupsi’ (2019), Vol. 1 No. 3 Jurnal Pembangunan Hukum Indonesia.[330].
} 
korporasi dan/atau pengurus dan/atau staff. Perbuatan penagihan dengan caracara yang berindikasi tindak pidana tersebut dilakukan oleh desk collector yang merupakan karyawan korporasi yang bertindak dalam lingkup pekerjaannya mewakili korporasi. Selain desk collector, penjatuhan pidana dapat dikenakan kepada korporasi yang seharusnya "dapat berbuat lain" selain melakukan tindak pidana. Keputusan korporasi dalam menagih pinjaman dengan ancaman dan mengakses data pribadi yang tidak diperbolehkan dapat dimintai pertanggungjawaban pidana. Sehingga pertanggungjawaban pidana dapat dikenakan pada korporasi dan staff.

Sesuai dengan Pasal 23 Perma Nomor 13 Tahun 2016, hakim dapat menjatuhkan pidana terhadap korporasi atau pengurus, korporasi dan pengurus, baik secara alternatif maupun kumulatif. Pertanggungjawaban pidana penyelenggara aplikasi virtual loan dapat dijatuhkan secara kumulatif yaitu kepada korporasi dan desk collector. Pertanggungjawaban pidana pengurus korporasi dapat berupa pidana penjara dan/atau pidana denda. Sedangkan pertanggungjawaban pidana korporasi hanya pidana denda sesuai Pasal 25 ayat (1) Perma Nomor 13 Tahun 2016. Dan berdasarkan Pasal 52 ayat (4) UU ITE, pidana pokok untuk tindak pidana yang dimaksud dalam Pasal 27 ditambah dua pertiga.

Untuk menilai kesalahan korporasi dalam penanganan pertanggungjawaban pidana korporasi, Pasal 4 ayat (2) Perma Nomor 13 Tahun 2016 menyebutkan 3 (tiga) bentuk kesalahan korporasi:

1. Korporasi mendapat keuntungan atau manfaat dari tindak pidana tersebut. Keuntungan yang diperoleh korporasi berasal dari tagihan yang awalnya tak tertagih menjadi telah ditagihkan yang didalamnya memuat biaya administrasi, biaya provisi dan denda keterlambatan pembayaran. Dengan ditagihkannya utang pada debitur, korporasi mendapatkan keuntungan dari bunga $0,5 \%$ per hari dari debitur yang terlambat membayar.

2. Korporasi membiarkan terjadinya tindak pidana. Pembiaran terlihat pada saat koordinator desk collection staff memperbolehkan menagih dengan cara apapun dan hanya menginginkan desk collector agar dapat mencapai target pembayaran sesuai dengan yang sudah ditentukan perusahaan. 
3. Korporasi tidak melakukan langkah-langkah untuk melakukan pencegahan terhadap dampak yang lebih besar. Terlihat di awal peminjaman, terdapat informasi palsu bahwa virtual loan telah diatur dan diawasi oleh OJK. Selain itu, terdapat klausula baku yang berisi debitur harus menyetujui pengaksesan data pribadi. Kemudian data pribadi tersebut dimanfaatkan untuk menagih utang debitur. Sehingga tidak mungkin penyelenggara melakukan langkahlangkah pencegahan.

Sehingga berdasarkan Pasal 52 ayat (4) UU ITE, pertanggungjawaban pidana dapat dikenakan pada korporasi dan/atau pengurus korporasi dan/atau staff. Dengan syarat bahwa korporasi tersebut merupakan korporasi dalam arti sempit (badan hukum). Sedangkan tata cara penanganan pertanggungjawaban pidana korporasi dapat dikaitkan dengan Pasal 4 ayat (2) Perma Nomor 13 Tahun 2016. Pertanggungjawaban pidana korporasi ini juga didukung dengan teori pertanggungjawaban pidana korporasi vicarious liability dan teori identifikasi.

Berikut adalah salah satu contoh putusan penagihan pinjaman online dengan ancaman kekerasan: Putusan Nomor 438/Pid.Sus/2020/PN Jkt.Utr Atas Nama Terdakwa Dede Supardi Alias Ipank. Ipank adalah desk collector yang bertugas mengingatkan tanggal jatuh tempo pembayaran. Namun dalam melakukan penagihan pinjaman, koordinator desk collector (Teddy) memperbolehkan desk collection staff untuk melakukan penagihan dengan cara apapun. Ipank melakukan penagihan dengan ancaman kekerasan kepada Mahdi Ibrahim dan Bayu Prasetya.

Perbuatan Ipank dipidana sesuai Pasal 45 ayat (4) jo. Pasal 27 ayat (4) UU ITE terkait pendistribusian informasi elektronik yang bermuatan penghinaan dan/ atau pencemaran. Dakwaan pertama dalam kasus ini yaitu Pasal 45 ayat (3) jo. Pasal 27 ayat (3) UU ITE terkait pendistribusian informasi elektronik yang bermuatan penghinaan dan/atau pencemaran tidak terbukti karena tidak memenuhi unsur Pasal 310 KUHP. Voice note dengan kata-kata: "Bangsat maling, gua sumpahin keluarga melarat sampe mati" dan "Woy anjing lo, ga bayar bayar-bayar anjing" tidak dalam maksud yang nyata akan tersiarnya tuduhan itu. 
Pengurus atau orang-orang yang berkepentingan di dalam korporasi dapat dipertanggungjawabkan secara pidana sesuai Pasal 56 KUHP. Konsep turut membantu berarti ia sengaja memberikan bantuan pada waktu atau sebelum kejahatan itu dilakukan. Turut membantu hanya melakukan perbuatan persiapan yang sifatnya menolong, tidak boleh melakukan anasir atau elemen dari perbuatan pidana. Pengurus korporasi yang menyediakan sarana berupa akses data pribadi untuk disalahgunakan oleh desk collector merupakan perbuatan turut membantu. Sehingga pengurus korporasi dapat dipidana sebagai pembantuan, sesuai Pasal 45 ayat (4) UU ITE jis. Pasal 27 ayat (4) UU ITE jis. Pasal 56 KUHP.

\section{Kesimpulan}

Penagihan pinjaman dalam aplikasi virtual loan yang dilakukan dengan ancaman, asusila dan pornografi merupakan tindak pidana di lingkup cybercrime. Cara penagihan oleh pelaku fisik desk collector yang mewakili penyelenggara aplikasi virtual loan memenuhi unsur-unsur perbuatan sebagaimana diatur dalam ketentuan Pasal 45 ayat (1) jo. Pasal 27 ayat (1) atau Pasal 45 ayat (4) jo. Pasal 27 ayat (4) UU ITE.

Perbuatan penagihan dengan cara-cara yang berindikasi tindak pidana tersebut dilakukan oleh penyelenggara virtual loan sendiri ataupun menghire pihak ketiga. Apabila dilakukan oleh penyelenggara virtual loan sendiri, pertanggungjawaban pidana dapat dikenakan pada korporasi dan staff. Berdasarkan Pasal 52 ayat (4) UU ITE, desk collector yang merupakan staff dalam melakukan tindak pidana bertindak dalam lingkup pekerjaannya mewakili korporasi. Penyelenggara virtual loan (badan hukum) yang mengambil keputusan menagih pinjaman dengan ancaman, asusila dan pornografi padahal seharusnya "dapat berbuat lain" dapat dimintai pertanggungjawaban pidana. Pertanggungjawaban pidana korporasi ini juga didukung dengan teori vicarious liability dan teori identifikasi. Berdasarkan putusan kasus PT. Vega Data Indonesia, terhadap penyelenggara virtual loan ilegal, pertanggungjawaban pidana ditujukan pada pengurus. Sehingga hanya desk collector dan pengurus korporasi sebagai orang sesuai Pasal 59 KUHP yang dapat 
2318 Dina Aprilia: Pertanggungjawaban Pidana Penyelenggara...

dipidana sebagai turut membantu sesuai Pasal 45 ayat (4) UU ITE jis. Pasal 27 ayat (4) UU ITE jis. Pasal 56 KUHP. Pemidanaan terhadap badan hukum yaitu pidana denda sesuai Pasal 23 Perma Nomor 13 Tahun 2016. Sedangkan terhadap pengurus korporasi dikenakan pidana penjara dan/atau denda.

\section{Daftar Bacaan}

\section{Buku}

Adami Chazawi dan Ardi Ferdian, Tindak Pidana Informasi\&Transaksi Elektronik (Media Nusa Creative 2011).

Agus Raharjo, Cybercrime: Pemahaman dan Upaya Pencegahan Kejahatan Berteknologi (Citra Aditya Bakti 2002).

H.A.K. Moch Anwar, Hukum Pidana Bagian Khusus Jilid I (Citra Aditya Bakti 1982).

Mahrus Ali, Asas-Asas Hukum Pidana Korporasi (RajaGrafindo Persada 2015).

R. Soesilo, Kitab Undang-Undang Hukum Pidana (KUHP) Serta KomentarKomentarnya Lengkap Pasal Demi Pasal (Politeia 1991).

Utrecht, Hukum Pidana I (Pustaka Tinta Mas 1987).

Wirjono Prodjodikoro, Tindak-Tindak Pidana Tertentu Di Indonesia (Refika Aditama 2003).

\section{Jurnal}

Abdurrakhman Alhakim, 'Kebijakan Pertanggungjawaban Pidana Korporasi Terhadap Pemberantasan Tindak Pidana Korupsi' (2019) Vol. 1 No. 3 Jurnal Pembangunan Hukum Indonesia.

Bunga Upe, Haerani Husainy dan Abd. Malik Bram, 'Tinjauan Yuridis Pencemaran Nama Baik Melalui Media Sosial’ (2019) Vol. 1 No.1 Jurnal Unismuh Palu.

Muhammad Naseh et al., 'Karakteristik Pelaku Kejahatan Transnasional Terorganisasi di Indonesia dan Eropa' (2019) Vol. 8 No. 1 Jurnal Hubungan Internasional.

Taufiq Widyanto, 'Perlindungan Hak Perempuan Perbuatan Asusila Ditinjau dari Perspektif Hukum Pidana' (2014) Jurnal Ilmiah Ilmu Hukum. 


\section{Perundang-undangan}

Undang-Undang Republik Indonesia Nomor 1 Tahun 1946 Tentang Peraturan Hukum Pidana (Berita Negara Republik Indonesia II Nomor 9).

Undang-Undang Nomor 11 Tahun 2008 Tentang Informasi Dan Transaksi Elektronik (Lembaran Negara Republik Indonesia Tahun 2008 Nomor 58, Tambahan Lembaran Negara Republik Indonesia Nomor 4843).

Undang-Undang Republik Indonesia Nomor 44 Tahun 2008 Tentang Pornografi (Lembaran Negara Republik Indonesia Tahun 2008 Nomor 181, Tambahan Lembaran Negara Nomor 4928).

Undang-Undang Nomor 19 Tahun 2016 Tentang Perubahan atas Undang-Undang Nomor 11 Tahun 2008 tentang Informasi Dan Transaksi Elektronik (Lembaran Negara Republik Indonesia Tahun 2016 Nomor 251, Tambahan Lembaran Negara Republik Indonesia Nomor 5952).

Peraturan Otoritas Jasa Keuangan Nomor 77/POJK.01/2016 Tahun 2016 tentang Layanan Pinjam Meminjam Uang Berbasis Teknologi Informasi. 
Dina Aprilia: Pertanggungjawaban Pidana Penyelenggara...

--halaman ini sengaja dibiarkan kosong-- 